\title{
O PARADIGMA DAS GLOBAL CITIES NAS ESTRATÉGIAS DE DESENVOLVIMENTO LOCAL
}

\author{
ROSE COMPANS
}

R E S U M O Este artigo trata das novas estratégias de desenvolvimento econômico para as cidades no contexto da reestruturação produtiva. Ele enfoca o papel atribuido às cidades como centros de gestão dos fluxos de capitais, o qual permite uma articulação entre o local e o global sem a intermediação das esferas regional e nacional. Primeiramente, apresenta as contribuiçōes teóricas no Terceiro Mundo que mais têm influenciado o debate urbano sobre a emergência de uma economia de fluxos, cuja organização em rede impóe as cidades como nós de conexão. Em seguida, analisa a construção paradigmática das global cities, com base na generalização de alguns pressupostos teóricos e de tendências empiricamente observadas. Finalmente, examina as estratégias que estão sendo difundidas por consultores internacionais e relacionadas à vocação inexorável das cidades para o terciário avançado. *

PALAVRAS-CHAVE Desenvolvimento local; gestão urbana; globalização; cidades mundiais.

* Trabalho selecionado da sessão temática 4 - "Urbano e regional: que novas territorialidades?"

\section{INTRODUÇÃO}

O debate sobre as estratégias de desenvolvimento local no quadro de reestruturação da economia mundial tem sido marcado pela redefinição do papel das cidades face o processo de descentralização produtiva e recentralização do controle sobre os fluxos de capitais, mercadorias e informações, com a constituição de novas hierarquias urbanas e territoriais. A emergência de uma nova economia de fluxos conferiria às cidades as funções de comando e produção de serviços altamente especializados, requeridos para o monitoramento dos investimentos realizados no exterior pelas grandes corporações internacionais.

Um enorme esforço teórico vem sendo produzido a fim de identificar as características destas "cidades globais", e o lugar que ocupam dentro desta nova ordem econômica mundial. Entretanto, algumas características e tendências identificadas por investigações científicas - que se utilizaram de pesquisas empíricas relativas a algumas das grandes metrópoles americanas e européias - têm sido apropriadas como o futuro inexorável das cidades, de uma forma geral, constituindo-se, assim, como um paradigma, um objetivo a ser perseguido por todas as localidades que pretendam inserir-se nos fluxos econômicos globais, fora dos quais não há esperança.

A disseminação deste paradigma estimula a competição interurbana e um mercado de modelos de gestão, que são ofertados por consultores internacionais interessados em divulgar experiências supostamente de sucesso, e demandados por administraçôes municipais interessadas em promover o desenvolvimento econômico local, pelo cumprimento de uma agenda "estratégica" com a qual possam assegurar a inserção competitiva de suas cidades. 
O objetivo do presente trabalho é o de rever os pressupostos constituintes deste paradigma das global cities, buscando estabelecer mediaçôes possíveis com a realidade dos países "periféricos", de maneira a conduzir uma reflexão crítica sobre a pertinência do discurso único produzido a respeito das estratégias de desenvolvimento local, nele teoricamente referenciadas.

Para tanto, iniciaremos com uma exposição bastante sintética de algumas das principais contribuiçōes teóricas acerca do novo "protagonismo" das cidades no contexto da globalização e de um novo ciclo de desenvolvimento impulsionado pelas novas tecnologias da informação que mais têm alimentado as discussōes na América Latina sobre o futuro das cidades. Procuraremos enfatizar as distintas abordagens e os aspectos nos quais elas divergem, em particular quanto à especialização funcional das cidades que, como veremos, varia de acordo com o acento colocado ora no aspecto determinante da oferta da infra-estrutura de telecomunicações, ora na existência de um mercado de trabalho qualificado e inovador ou, ainda, na existência de sistemas de controle herdados do período anterior, como o são as principais bolsas de valores.

Em seguida, passaremos à análise da maneira pela qual estas abordagens se deslocam do contexto histórico, particular e concreto da realidade dos países centrais no qual foram formuladas para abranger o conjunto da economia e das sociedades. O duplo movimento de generalização de tendências observadas - tanto na organização empresarial de determinadas atividades econômicas, quanto na especialização financeira e de serviços avançados de algumas metrópoles - é autorizado pela hipótese teórica da interdependência cultural e econômica global, bem como pela suposta evidência empírica de sua manifestação em sociedades asiáticas e latino-americanas.

Finalmente, na terceira parte deste ensaio enfocaremos as estratégias de desenvolvimento local que, com base em uma construção paradigmática sobre o papel econômico das cidades na globalização, visam antecipar as tendências anunciadas, oferecendo ao capital todas as condiçôes materiais e imateriais para sua mobilidade e gestão, de forma a estimular a localização dos centros de decisão empresarial no interior delas. A subordinação reconhecida, e passivamente aceita, à lógica por vezes especulativa da mobilidade do capital, e a negligência quanto às especificidades locais e nacionais e quanto ao caráter regressivo dos investimentos públicos propostos são alguns dos aspectos mais surpreendentes destas estratégias.

\section{ECONOMIA DE FLUXOS, GEOGRAFIA DE REDES}

Uma primeira abordagem do novo papel das cidades é aquela que acentua sua gênese à emergência de um novo modelo de organização sociotécnica da produção com a introdução das novas tecnologias da informação simultaneamente à restruturação do capitalismo, em particular no que concerne ao processo de internacionalização do capital que, juntos, estariam conformando um novo "espaço de fluxos" em substituição ao "espaço dos lugares". O elemento central da produtividade no novo modo de desenvolvimento informacional, que sucede ao industrial, baseia-se agora na qualidade do conhecimento e no processamento da informação, convertida ao mesmo tempo em matéria-prima e produto, e não mais nas fontes de energia e na qualidade do seu uso como no modelo anterior.

Este novo paradigma tecnológico é o ponto de partida da démarche de Castells em The Informational City, cujas características organizacionais estariam redesenhando a geografia econômica mundial - entre elas, o aprofundamento da divisão histórica entre tra- 
balho manual e intelectual, com a crescente concentração de processos de geração de conhecimento e tomada de decisões em organizaçōes de alto nível, consideradas as únicas indispensáveis, concomitantemente à precarização das relaçôes salariais do trabalho de execução de tarefas, dispersão espacial, subcontratação ou automação.

Analisando as estratégias de localização das indústrias de semicondutores e de informática americanas, ele observa que, enquanto muitas delas mantiveram suas sedes em seus locais de origem, onde desenvolveram centros internos de investigação científica (IBM, ATT-Bell e Motorola), outras buscaram a proximidade de complexos universitários importantes como Harvard, Stanford e Berkeley ou, como no caso específico da indústria de software, a proximidade a determinados centros urbanos que ofereciam serviços financeiros e um "meio de informação" criativo, capaz de gerar novas idéias e novas técnicas pelo intercâmbio e a interação de elementos concentrados espacialmente em uma rede própria de relações sociais.

Em ambas, nota que os aspectos da acessibilidade e da qualidade de vida oferecidos são igualmente cruciais para a escolha da localização das sedes empresariais e dos centros de produção chaves. Esta localização corresponde a centros nodais de uma rede de telecomunicaçōes e transporte aéreo que permitem às empresas descentralizar atividades de fabricação com vistas ao incremento de rentabilidade e expansão de mercados, mas também atende às exigências sofisticadas de consumo do pessoal altamente qualificado, do qual depende o desenvolvimento das indústrias baseadas na informação. Contrariamente ao modelo industrial tradicional, verticalizado, em que os fatores de localização eram custo de transporte e abundância de matéria-prima, a segmentação interna do processo produtivo proporcionado pelas novas tecnologias da informação permite às novas indústrias operarem em escala mundial por meio de redes telemáticas.

Esta dialética entre descentralização e necessidade de centralização, que fortalece hoje o papel econômico das grandes metrópoles, Castells identifica também no setor de serviços à produção, sobretudo naqueles intensivos em informação, como bancos, seguros, consultorias diversas, contabilidade, advocacia, agências comerciais, entre outros, que representavam 13,9\% do emprego americano em 1985, dos quais 39\% encontravam-se nas 24 maiores áreas metropolitanas. Os escritórios centrais das grandes empresas prestadoras de serviços em escala nacional e internacional tendem a se concentrar nos distritos financeiros das grandes metrópoles, que dispõem de linhas de comunicação de larga distância em fibra ótica e permitem o acesso aos satélites de telecomunicações por meio de estações terrestres (teleportos) e que podem ser compartilhadas por várias empresas em redes locais ou edifícios inteligentes.

Além do acesso às redes de fibra ótica, em distritos financeiros como Manhattan circulam "microfluxos de informação", ou seja, intercâmbios ocasionais e informação nãopública, que se traduzem em posiçōes de competitividade privilegiada, domínio sobre as estratégias dos concorrentes e tomadas de decisões mais apropriadas. Castells chega mesmo a afirmar que o fato de as empresas de valores superarem os bancos comerciais como centros nevrálgicos do processo de acumulação demonstra que sua ênfase hoje repousa menos nos desenvolvimentos internos das grandes empresas financeiras e mais no ambiente de intercâmbios tecido em torno dos mercados financeiros, com seu núcleo na bolsa de valores.

A contribuição de Saskia Sassen $(1995 ; 1996)$ neste debate será fundamental, porque ela se utiliza de grande parte da démarche de Castells, mas a ultrapassa colocando de lado um certo determinismo tecnológico aí presente, para acentuar o fenômeno da expansão 
da indústria financeira, decorrente da extraordinária mobilidade do capital induzida pela dispersão geográfica do setor industrial, não apenas por deslocamentos massivos de plantas industriais, mas, sobretudo, graças à transnacionalização da propriedade por intermédio do investimento estrangeiro direto (IED) em açóes, bem como por fusões, aquisiçốes e formação de joint ventures.

Esta mobilidade engendrou uma demanda das grandes sociedades dos países industrializados por certos tipos de produção essenciais para assegurar a gestão e o controle desta "rede mundial de sítios de produção", do qual o desenvolvimento das telecomunicações é apenas um entre muitos requisitos. Os serviços altamente especializados são os novos inputs básicos para a gestão, tornada cada vez mais complexa, de uma rede de usinas, escritórios e mercados financeiros secundários, e incluem a produção de um vasto conjunto de novidades para estes setores. Por outro lado, a mudança ocorrida no perfil do mercado financeiro no decorrer da década de 1980, com a participação crescente e proliferação de instituições como fundos de pensão, companhias de seguro e pequenas sociedades, renovando e ao mesmo tempo expandindo este mercado, igualmente irá demandar e produzir novos serviços especializados.

Sassen identifica no fenômeno da "bolsificação" dos capitais, isto é, na transformação dos diferentes tipos de ativos e dívidas em instrumentos de mercado, o veículo desta evolução e da expansão concomitante do volume global dos mercados financeiros. O crescimento dos investimentos em ações foi inversamente proporcional ao declínio dos empréstimos bancários. $\mathrm{O}$ fator central desta transformação foi a emissão de títulos pelas grandes sociedades, seguidas pelas de tamanho médio, que descobriram nesta uma forma mais barata de obter recursos financeiros do que recorrendo aos bancos.

Além disso, a dispersão geográfica do setor industrial vai engendrar a internacionalização do setor de serviços, num movimento de acompanhamento de abertura de filiais no exterior, ainda que em uma escala muito mais reduzida. Isto porque, com a descentralização da produção, as unidades fabris irão requerer o fornecimento de serviços específicos nos quais a proximidade a elas próprias e aos mercados de consumo, e o domínio da legislação nacional são imprescindíveis, como as atividades ligadas ao comércio exterior, publicidade e marketing, contabilidade, consultorias jurídicas, manutenção de equipamentos etc.

Os pontos nodais de todas estas redes complexas são em Sassen, como em Castells, as grandes metrópoles, porém não somente pela infra-estrutura de telecomunicações de que dispõem, e pelo "meio de inovação" e a qualidade de vida que oferecem às funções de comando, concepção e gestão das grandes empresas multinacionais. Em Sassen, estes "sítios de controle específicos", aos quais denomina de "cidades globais", são principalmente praças financeiras e lugares de produção de serviços especializados que dão capacidade de controle mundializado.

É o complexo de empresas prestadoras de serviços à produção, mais do que as sedes sociais das grandes corporaçôes multinacionais, que mais tira proveito das economias de aglomeração proporcionadas pela localização metropolitana e mesmo dela tem necessidade, na medida em que funciona como um sistema de produção em que estão presentes relaçôes de interdependência que não podem prescindir da proximidade física. Sassen lembra, como exemplo, que a produção de um instrumento financeiro requer hoje um tal número de inputs - de contabilidade, publicidade, consultoria jurídica, econômica, relaçōes públicas, designers etc. - que tornar-se-ia praticamente impossível produzi-lo isoladamente e fora do contexto urbano, ainda que se dispusesse de todos os recursos da telemática. 
Este novo caráter produtivo da comunicação e da cooperação social é o elemento central da análise de Pierre Veltz (1996), que identifica a tendência à metropolização da economia mundial, cuja dinâmica estaria conduzindo a uma organização territorial policêntrica sob a forma metafórica de um arquipélago. Ele radicaliza os argumentos de Castells e Sassen, porque não restringe o fenômeno da concentração urbana a determinados setores - alta tecnologia, finanças e serviços -, generalizando-o para o conjunto das atividades econômicas inseridas na nova forma de concorrência pela diferenciação - e não mais apenas por preços, como no período taylorista - em que a qualidade, variedade, capacidade de inovação e de reatividade ao mercado consumidor passam a ser os critérios fundamentais da competitividade.

A incapacidade da organização taylorista rigidamente verticalizada de responder a estes novos critérios de competitividade impulsionou as firmas a um movimento simultâneo de segmentação e subcontratação de tarefas, com a redução do tamanho médio dos estabelecimentos, e multilocalização, isto é, especializar as unidades e coordenar a rede logística. A multilocalização de unidades produtivas especializadas permite às firmas melhor mobilizar competências específicas locais, reduzir os riscos ligados às flutuaçôes do mercado, amortizar custos ligados à pesquisa e desenvolvimento e à publicidade, por meio da multiplicação de alianças e cooperaçôes, bem como criar posiçōes de negociações mais favoráveis com fornecedores, clientes e/ou consumidores.

Por outro lado, esta nova forma de concorrência pela diferenciação da qual deriva este novo modelo organizacional em rede, vai requerer determinados "potenciais extra-econômicos" que só a localização metropolitana pode oferecer: uma mão-de-obra muito mais qualificada; uma capacidade coletiva de supremacia sobre sistemas técnicos frágeis e sofisticados; o desenvolvimento de relaçóes de confiança entre atores econômicos cada vez mais interdependentes; além de "externalidades" do meio-ambiente físico.

As grandes cidades mundiais são formidáveis máquinas de acelerar fluxos, de ligar os ritmos do consumo e dos modos de vida com os da produção e do capital, de limitar a incerteza garantindo às firmas possibilidades maiores de "externalização" dos riscos e também de apropriação das "externalidades imateriais" - o conjunto de conhecimentos difusos, de comportamentos e de disciplinas interiorizadas na vida social em geral; o nível técnico e cultural dos trabalhadores; a circulação de conhecimentos informais e formais existentes nas redes de relaçôes socioprofissionais etc. -, e o acesso aos mercados mais flexíveis de trabalho e de prestação de serviços. Para Veltz, a metropolização não é somente a forma que envolve os grandes processos econômicos atualmente, mas a sua própria substância.

Nesta perspectiva é que ele sugere a hipótese de que, com a multiplicidade destes pólos de atividades metropolitanas especializadas, os fluxos e as interdependências em larga escala de bens e serviços produzidos em outros pólos determinariam a intensificação das relações horizontais entre eles, em detrimento das relaçōes verticais do tipo centro/periferia que caracterizaram a organização territorial taylorista. Tal hipótese seria sustentada empiricamente pelo aumento significativo de vôos entre Paris, Londres, Frankfurt, Bruxelas, Amsterdã, Genebra, Milão e Turim, comparativamente a outras destinaçôes, nos últimos anos, e pela concentração de filiais de empresas multinacionais neste "anel central multipolar" europeu.

As conexôes destas redes por meio dos sistemas de transporte de grande velocidade e de telecomunicações, entretanto, estariam provocando "efeitos de túnel" por zonas atravessadas e não conectadas, que desenham assim um território descontínuo e fraturado, onde se observam afastamentos cada vez maiores, em todas as escalas, entre zonas integradas e zonas periféricas e abandonadas. 
A teoria dos distritos industriais marshallianos também viria contribuir neste debate, tendo como ponto de partida as pesquisas sobre o fenômeno da "Terceira Itália", considerado uma experiência bem-sucedida de "desenvolvimento local endógeno", ou seja, devido essencialmente à sua dinâmica interna, cujas características fundamentais poderiam ser também encontradas nas grandes metrópoles, como nos distritos de alta tecnologia - eletrônica e aeronáutica -, de confecção, de cinema e televisão, além do distrito comercial e financeiro central, existentes na cidade de Los Angeles, como observa Allen Scott (1992).

A hipótese do autor é que quanto maior for a divisão social do trabalho presente numa dada localidade, isto é, o fracionamento dos encadeamentos da atividade econômica em algumas unidades especializadas independentes - a desintegração vertical da produção -, maior será a probabilidade de os produtores que operam em pequena escala, com contatos muito mais freqüentes e variados com fornecedores, subcontratados e clientes, de aí estabelecerem economias externas ligadas à proximidade espacial. E as grandes cidades são os lugares onde esta divisão social do trabalho é mais fortemente desenvolvida, facilitando a formação de distritos industriais.

Elas o são, em primeiro lugar, porque suas bases econômicas são constituídas por uma miríade de funçōes especializadas interligadas por redes transacionais complexas. Em segundo, porque certos setores industriais foram obrigados a fragmentar sua cadeia de produção, uma vez submetidos a um mercado concorrencial pela diferenciação, num ambiente de incerteza e flutuaçôes econômicas constantes, conformando um sistema de unidades reunidas por um denso tecido de relações intrafirmas. A metrópole é, assim, um pólo de distritos industriais por excelência.

Todavia, este processo de desindustrialização/reindustrialização não foi uniforme nem linear. Ele foi especialmente intenso para os sistemas produtivos nos quais as tarefas complexas e variadas são mais acentuadas e em que os produtos atravessam numerosas etapas de produção, mas não em outros. Isto explica por que, embora tenham sido criados 225.800 empregos industriais em Los Angeles na década de 1980 - enquanto Nova York perdia 330.000, no mesmo período - ocorreu um declínio do emprego na chamada "indústria pesada" acompanhado de aumento do desemprego, pobreza, violência, trabalho informal, entre outras chagas sociais (Soja, 1993).

Como adverte Scott, os setores que mais bem se adaptaram à reconversão produtiva flexível e que, por isso, provocaram um retorno à aglomeração e ao crescimento urbano, foram aqueles baseados na habilidade e na qualidade da informação, e nos quais prevalece a diferenciação dos produtos, como as indústrias artesanais do vestuário, a mobiliária, joalheria, as indústrias de alta tecnologia, os serviços à produção e financeiros etc. Apesar de Los Angeles apresentar todos estes setores, eles produzem espacialidades distintas no interior da metrópole: o lugar central, comercial e financeiro, de onde se exerce a influência da cidade sobre a economia do Arco do Pacífico; os distritos industriais descentralizados, baseados na qualificação, como cinema, televisão e confecçãa; os tecnopólos fundados na tecnologia aeroespacial e na eletrônica, que contornam a metrópole num anel periférico.

O que é surpreendente na contribuição de Scott é o caráter ainda tipicamente industrial que pode assumir o desenvolvimento urbano, negligenciado nas análises anteriores que pareciam sugerir uma especialização financeira e de serviços avançados das economias metropolitanas. Paradoxal e paradigmático, o crescimento urbano e econômico recente da metrópole californiana aponta na direção de uma pluralidade de alternativas possíveis para o desenvolvimento das cidades, para além de todos os determinismos. 
Com efeito, esta "pluralidade de mundos possíveis de produção" é sublinhada por Salais \& Storper (1993). Baseados na comparação entre sistemas produtivos verificados na França, na Itália e nos EUA, os autores concluem que existem hoje quatro formas de organização produtiva, distintas em razão de alguns condicionantes, como o tipo do produto, os esquemas de coordenação baseados em convenções próprias, e dos objetos que manipula (máquinas e equipamentos, matérias-primas, regras escritas etc.). Estes "mundos" seriam: a) o mundo da produção imaterial - aquele da inovação, das novas tecnologias, bem como da criação de novas necessidades e propriedades de uso; b) o mundo interpessoal dos produtos especializados fabricados segundo competências e saberes especializados próprios - aquele dos distritos industriais marshallianos; c) o mundo mercadológico dos produtos estandardizados, mas dedicados a uma demanda particular aquele da produção em massa, cuja empresa foi restruturada e flexibilizada; d) e o mundo industrial - tal como nos é familiar - aquele da produção em massa estandardizada que ainda persiste em diversos setores. A acumulação flexível não é preponderante por toda parte, como, de resto, o fordismo também não o fora.

Finalmente, uma última abordagem sobre o novo papel das grandes cidades pode ser encontrada na reflexão de David Harvey $(1994 ; 1995)$ a respeito da emergência da pósmodernidade como expressão cultural de um novo regime de acumulação, flexível, em substituição ao regime de acumulação fordista. Sua démarche parte do pressuposto de que um regime de acumulação não se apóia apenas em determinada organização sociotécnica da produção, mas se traduz nos modos de vida social, aí compreendidas suas formas de consumo. A aceleração dos ritmos da produção e da inovação, igualmente observada pelos outros autores, implica a aceleração dos ritmos do consumo, algo que requer como contrapartida uma mudança no padrão do consumo. A difusão da cultura do efêmero e do descartável, que envolve a manipulação do gosto e da opinião, e a construção de novos sistemas de valores comportamentais e estilos de vida são condiçôes necessárias, ainda que não suficientes, do regime de acumulação flexível, para as quais se destaca a importância da indústria cultural e das mídias, essencialmente urbanas.

As cidades são o lugar privilegiado onde gostos, modos de vida e estilos são permanentemente criados e recriados, onde a volatilidade da moda pode ser mobilizada e apropriada, e onde a cultura pode ser mercantilizada, assim como somente nelas se situam os trabalhadores "imateriais" que são os produtores e/ou manipuladores destes novos sistemas de signos e imagens, dos quais necessitam agora mais do que nunca as firmas. Longe de ser uma observação marginal à problemática da organização territorial operada pela reestruturação econômica, a capacidade de produção de imagens associadas a padróes de consumo tornar-se-á, como veremos, um elemento diferencial na competição das cidades pela atração das empresas, do qual resultarão estratégias de marketing e de embelezamento urbanos.

\section{O PARADIgMA DAS GLOBAL CITIES}

O que denominamos aqui de paradigma das global cities é a apropriação de algumas idéias oriundas do debate da geografia econômica concernentes ao novo papel das cidades no quadro de reestruturação produtiva e da globalização, descoladas dos contextos nos quais foram formuladas, e, assim, reproduzidas como leis positivas cuja validade dispensa mediaçōes e relativizaçōes temporais e históricas, uma vez tendo sido comprovadas empiricamente. Tratam-se das tendências à especialização financeira e de serviços avançados 
nas cidades; do papel determinante das telecomunicaçoes para a centralização das funções de comando e controle sobre uma rede de fluxos econômicos em escala planetária; e da ligação entre o local e o global sem a intermediação do regional ou do nacional.

A formulação de tais hipóteses, como vimos, apóia-se na fenomenologia das transformações econômicas e urbanas observadas em algumas grandes cidades dos países que são os maiores exportadores e captadores do investimento estrangeiro direto - Nova York, Los Angeles, Londres, Paris e Tóquio -, o que, se não desqualifica absolutamente o enorme esforço teórico realizado para compreendê-las, sugere entretanto que a generalização de sua capacidade explicativa deve ser objeto de uma reflexão mais aprofundada.

O conteúdo paradigmático destas hipóteses resulta da não-associação dos fenômenos observados nestas cidades - mudanças profundas na estrutura do emprego, com o crescimento extraordinário do setor de serviços em detrimento da indústria, seguido de um boom econômico - às estruturas macroeconômicas tradicionais de divisão desigual do poder e da riqueza no mundo, seja qual for o critério de análise espacial desta divisão histórica: países desenvolvidos versus aqueles em via de desenvolvimento; hemisfério Norte versus hemisfério Sul; centro versus periferia etc. Esta negligência fundamental, além de proporcionar uma visão promissora sobre o futuro das cidades na era da globalização, sugere uma autodeterminação competitiva, na medida em que atribui a fatores endógenos o desenvolvimento alcançado por estas cidades. Analisemos alguns de seus aspectos.

\section{O Determinismo TeCNOlóGico}

A expressão global cities foi cunhada por Saskia Sassen, em 1991, para designar os pontos nodais dos fluxos financeiros a partir dos quais se produz um controle global dos mercados financeiros secundários e sítios de produção dispersos, na medida em que o investimento estrangeiro direto ocorre hoje preferencialmente pelo mercado de ações e de títulos. O lugar central ocupado pelas cidades de Nova York, Londres e Tóquio nesta rede de fluxos econômicos global é atribuída à concentração de importantes recursos e infra-estruturas "muito menos móveis do que se imagina." ${ }^{1}$ Entre estes, ela destaca a capa-

1 Entre os indicadores com os quais a autora trabalha está a capitalização das bolsas de valores. Em 1989, dos 10,1 trilhões de dólares movimentados por todas as bolsas de valores no mundo, as do Japão movimentaram 4,1 trilhões (sendo a Bolsa de Tóquio a maior do mundo), as dos EUA, 3,0 triIhões, e as do Reino Unido, 823 bilhões (Sassen, 1996, p.249). cidade de comunicação/transmissão de dados mundializada que depende de uma sofisticada infra-estrutura de telecomunicaçōes e de transportes de alta velocidade, cujos custo de construção e uso são bastante elevados, sem contar as despesas de atualizações permanentes das novas tecnologias, o que cria um obstáculo à entrada de outras cidades a esta restrita rede.

No caso japonês, esta capacidade de controle mundial requereu pesados investimentos na construção de um sistema novo de telecomunicações e do Teleporto City, na Baía de Tóquio, formado por edifícios "inteligentes", além de diversos projetos na área de transportes, como o TGV ligando a capital às cidades de Osaka e Nagoya. Com efeito, já em 1982, Tóquio apresentava fortes indicadores de concentração de serviços especializados ligados à informação: nada menos do que $84,7 \%$ das emissões de televisão, artigos de jornal, cartas, chamadas telefônicas e outras transmissões de informações (Sassen, 1996, p.453).

No caso dos EUA, são somente as grandes metrópoles que dispõem das novas linhas de comunicação em redes de fibra ótica, que seguiram as linhas ferroviárias, reforçando os pontos nodais dos sistemas de comunicações americanos herdados do século passado. Por outro lado, a concentração empresarial já existente nestes grandes centros é o elemento que justifica o alto investimento em infra-estruturas de telecomunicações, que atrai ca- 
da vez mais novas empresas num movimento de causação circular, pois o custo destes novos equipamentos será tanto mais barato quanto maior for a concentração empresarial existente (Castells, 1995, p.218).

Além das comunicações de longa distância, novas instalações para organizações de base regional também foram projetadas em vinte estados americanos, em teleportos que permitem o acesso aos satélites de comunicaçôes por estações terrestres em linhas de fibra ótica, ao qual se articulam áreas e edifícios "inteligentes". A realidade de uma "cidade cabeada" com uma diversidade de tecnologias de comunicação voltadas para as empresas (como as oferecidas no distrito financeiro de Manhattan, que, nos seus poucos hectares, concentra $60 \%$ dos empregos de Nova York), dá uma enorme versatilidade ao sistema e, neste sentido, facilita a concentração das grandes empresas nestes centros nodais. A disparidade em termos de acessibilidade e telecomunicações, em comparação com os EUA, é o que leva Castells a encarar como residual a possibilidade da descentralização das funções de controle em direção ao Terceiro Mundo, em busca de salários mais baixos. ${ }^{2}$

Entretanto, Castells e Sassen concordam que outras razōes concorrem para a centralização da operação dos fluxos financeiros em nível mundial, em Nova York, Londres e Tóquio, embora ambos admitam o surgimento de centros financeiros de segundo nível. Entre estas razões encontram-se a existência de um mercado de trabalho altamente qualificado e de um sistema de produção de inputs especializados e tecnologias financeiras avançadas, de complexos organizativos que funcionam como base material do processamento da informação e tomada de decisões sobre o fluxo do capital e, ainda, a constituição de um "meio de inovação tecnológica". Castells adverte sobre o caráter de não-reprodutibilidade destes fatores de centralização, uma vez tendo sido formados em condições históricas específicas e circunstâncias já inexistentes.

Têm requisitos de localização [os centros financeiros principais] que não podem se reduzir a uma boa infra-estrutura de telecomunicaçóes. Embora o surgimento de Hong Kong e de Singapura como centros financeiros de segundo nível atestem a possibilidade do surgimento de novas localizações sobre a base de uma política deliberada de organizar um mercado em uma localização determinada, os centros financeiros de alto nível, dirigindo operações a uma escala global, têm raízes históricas e geográficas, ligadas a seu papel nas economias nacionais e internacionais. (Castells, 1995, p.472)

A "política deliberada" que introduziu estas duas cidades asiáticas, citadas por Castells, na rede de centros financeiros mundiais, todavia, resultou menos da ação voluntarista dos governos nacionais ou locais do que das estratégias de descentralização produtiva da indústria americana, em busca de novos mercados, apoio governamental e mão-de-obra barata. Como sublinha Sassen, o sudeste asiático tornou-se, na década de 1980, o principal local de implantação para o investimento estrangeiro direto destinado à indústria, e esta descentralização e deslocalização das fábricas, acompanhadas por escritórios e unidades de prestação de serviços contribuíram para favorecer a criação de centros regionais secundários, "versōes reduzidas e nacionais do que Nova York, Londres e Tóquio asseguram em escala mundial” (Sassen, 1996, p.41).

Ora, se a construção de infra-estruturas de comunicação, de teleportos e edifícios "inteligentes" junto aos quais se implantarão os centros financeiros - uma das principais estratégias de desenvolvimento local erigidas sob o paradigma das global cities, como veremos - é condição necessária, porém insuficiente, para a concentração das funções de co-
20 autor se apóia no fato de que, em 1985, os empregos nas chamadas indústrias de informação americanas, fora dos EUA, não atingiam dez mil postos de trabalho (Castells, 1995, p.240). 
mando dos fluxos econômicos globais, o mesmo se pode dizer com relação à oferta de serviços avançados como consultorias jurídicas, informática, contabilidade, marketing, entre outros, haja visto que tais serviços também se expandiram em escala internacional. Eles podem ser fornecidos pelas filiais das grandes empresas em qualquer parte do planeta que seja provida de sistemas de telecomunicaçōes.

Da mesma forma que o custo elevado para a implantação das infra-estruturas de comunicação é um argumento insustentável para se invocar a sua não-reprodutibilidade (mesmo cidades do Terceiro Mundo, como o Rio de Janeiro, constroem hoje teleportos com recursos próprios), o longo prazo de investimento em recursos humanos para criar um mercado de trabalho qualificado ou um "meio" profissional inovador, capaz de produzir novidades financeiras ou inputs especializados, não justifica a extraordinária concentração da indústria financeira e da prestação de serviços à produção altamente especializados em um número tão limitado de cidades. Ou será que o Silicon Valley, no condado de Santa Clara, e outras tantas experiências recentes de tecnopólos surgidos à margem de grandes centros urbanos, não criaram em seu interior este "meio" inovador, atraindo volumosos investimentos em Pesquisa \& Desenvolvimento $(\mathrm{P} \& \mathrm{D})$ ? Não, nem a tradiçãao, nem um saber técnico-profissional só existente nos grandes centros urbanos dos países centrais podem explicar a inércia dos poderosos "microfluxos de informação" presentes nestas cidades globais.

Sassen (1995), num artigo mais recente, se surpreende ao analisar como os níveis de concentração da indústria financeira se mostram intocáveis, mesmo se a acirrada competição entre cidades e os progressos massivos nas telecomunicações permitiram uma hipermobilidade das praças financeiras. Entre 1980 e 1991, em que pese os empréstimos bancários internacionais terem sido multiplicados por cinco, Nova York, Londres e Tóquio mantiveram-se responsáveis por cerca de $42 \%$ destes empréstimos. Esta concentração, segundo Sassen, tem levado os países envolvidos na formação do mercado único e do sistema financeiro europeu a considerar a necessidade, para torná-lo competitivo, de centralizar também as funções financeiras e o capital em um número limitado de cidades, ao invés de manter a estrutura atual, na qual cada país possui seu próprio centro financeiro.

Não podendo mais sustentar que apenas a qualidade intrínseca destes supercentros, pela concentração da oferta de tecnologias financeiras mais avançadas, conduz, num movimento de causação circular, a esta extraordinária concentração da movimentação financeira nos mesmos centros, a autora conclui que os altos riscos envolvidos nestas operaçōes, dadas a volatilidade dos fluxos, as flutuações constantes das moedas, enfim, a incerteza e a especulação que caracterizam este mercado de papéis, leva os investidores a preferirem os mercados seguros dos países centrais.

[A concentração] é também, em parte, conseqüência de conjunturas macroeconômicas diversas, especialmente os riscos elevados corridos nos novos mercados, simultâneos à facilidade com a qual o dinheiro pode ser deslocado, como o mostra a verdadeira fuga dos mercados ditos emergentes após a desvalorização do peso mexicano, em dezembro de 1994, e a crise financeira que a partir dela se seguiu para os investidores estrangeiros. (Sassen, 1995, p.45)

Por outro lado, ela argumenta que esta "segurança" dos investidores passa, ainda, pelas funçôes regulatórias do Estado nacional, que permanece como o "garantidor último" dos direitos do capital mundializado, do respeito aos contratos firmados e dos direitos ligados à propriedade. Esta capacidade regulatória do Estado nacional neste domínio não 
pode ser reproduzida por outros arranjos institucionais privados, já que ele se baseia em última instância no poder militar. As evidências empíricas desta reflexão já haviam sido trabalhadas por Sassen em The Global City (cuja primeira edição, em inglês, data de 1991), em que, ao desenhar a nova geografia da hierarquia urbana mundial, observa que, ao lado da extrema concentração da captação de investimentos nos países do OCDE - que absorveram 94,3\% destes, em 1989 -, verifica-se o crescimento de transaçôes de curto prazo, altamente especulativas, em direção a mercados financeiros secundários como Singapura, Hong Kong e São Paulo, além de outros centros menos importantes (Sassen, 1996, p.128)

Ou seja, o capital não é assim tão transnacional e despatriado quanto possa parecer, e a articulação entre o local e o global - o núcleo duro do paradigma que sugere a nãopertinência do espaço, Estado e economia nacionais para o desenvolvimento econômico das cidades, bastando para tanto estratégias endógenas de atratividade e inserção nas redes dos fluxos econômicos globais - não corresponde à lógica do investimento estrangeiro que segue obedecendo as antigas relaçôes entre centro e periferia. A crise dos mercados financeiros asiáticos, em 1997, assim como a crise mexicana de 1994 e a débacle que representou para a economia dos países do Terceiro Mundo, como o Brasil, a fuga massiva de capitais que se seguiu a ela ilustram bem a fragilidade das proposiçôes otimistas dos novos "vendedores da esperança", que serão objeto da seção seguinte, baseadas numa articulação do local com o global, sem que esteja fortemente ancorada no desenvolvimento da economia regional e nacional.

\section{O LOCAL E O GLOBAL}

Borja \& Castells consideram que é na articulação entre o local e o global que se encontra, em última instância, "a fonte dos novos processos de transformação urbana, e, portanto, os pontos de incidência de políticas urbanas, locais e globais, capazes de inverter o processo de deterioração da qualidade de vida nas cidades" (1998, p.35). Tal otimismo reside na constatação empírica de que os novos processos produtivos "estrategicamente dominantes", os serviços avançados e a indústria de alta tecnologia, são aqueles que apresentam o maior dinamismo econômico, com o mais rápido crescimento no emprego e na proporção do PIB da maioria dos países, e são, como vimos na primeira parte deste trabalho, essencialmente urbanos. Eles seguem um modelo hierárquico de concentração metropolitana, constituindo uma rede policêntrica com três níveis de hierarquia urbana:

a) as funções mais importantes em termos de qualificação, poder e capital, como as finanças internacionais, consultorias e serviços às empresas no âmbito internacional, se concentram nas principais áreas metropolitanas do mundo, ou seja, em Nova York, Londres e Tóquio;

b) as funçôes de segundo nível, mas também ligadas à gestão global, e alguns segmentos de mercados específicos - como o de opçóes de futuro - , concentradas em grandes cidades mundiais, como é o caso de Chicago, Los Angeles, São Francisco, Hong Kong, Singapura, Osaka, Frankfurt, Paris, Zurique, Amsterdã e Milão;

c) as funções destinadas à incorporação de novos mercados, na medida em que a rede de interaçōes em que se baseia a economia global se estende, fazendo emergir "centros regionais", como as cidades de Madri, Barcelona, São Paulo, Buenos Aires, México, Taipei e Moscou. 
Embora reconheçam que todos os indicadores assinalam um aumento da concentração das funçôes de controle em algumas poucas metrópoles, estes autores acreditam que nada pode assegurar a permanência desta hierarquia urbana, exatamente porque ela está sujeita a uma competição feroz em setores bastante voláteis como finanças, informática ou incorporação imobiliária. A competição entre as cidades deveria refletir a competição das empresas, que, na busca de incrementos de produtividade, procurariam se situar naquelas localidades que mais oferecessem condições materiais, sociais e institucionais para tanto. Que vençam as melhores!

Borja \& Castells, no entanto, advertem que existem ainda obstáculos para esta concorrência perfeita. Trata-se da concentração locacional da informação, elemento central da competitividade empresarial neste setor, atribuída aos altos níveis de incerteza induzidos pelas mudanças tecnológicas, pela desqualificação do mercado de trabalho, pela desregulação e pela globalização do mercado, mas também às consideráveis inversões imobiliárias das grandes empresas nos ditos centros direcionais da economia mundial, que se desvalorizariam em caso de uma relocalização massiva. Contudo, a possibilidade de alteração nos níveis da hierarquia urbana não deve ser descartada na medida em que uma regulação futura dos mercados internacionais, que reduza a incerteza sobre as regras do jogo econômico e sobre seus jogadores, poderá ocasionar uma menor concentração da indústria da informação, com o deslocamento de unidades de produção e de distribuição em direção aos níveis inferiores da hierarquia urbana.

Não obstante, diversos centros regionais de gestão de serviços têm emergido nos EUA, na Europa e na Ásia, bem como uma rede dispersa e articulada nas periferias das regiôes metropolitanas. Em geral, "a maior parte destas atividades de serviços descentralizadas em direção à periferia são compostas por trabalhos de oficina rotineiros destinados ao processamento massivo e automatizado da informação, e empregam pessoal feminino insuficientemente remunerado" (Borja \& Castells, 1998, p.42). Em outras palavras, na pior das hipóteses, a integração das nossas cidades a esta "rede interdependente e hierarquizada de complexos produtores de serviços a partir dos fluxos de informação telecomunicados" (idem) poderá contribuir com a renda familiar das camadas pobres, ainda que pela exploração do trabalho das mulheres.

Em que pese o "futuro" modesto reservado à periferia nesta dinâmica competitiva, esta admite, na visão dos autores, maiores perspectivas de autonomia local e de alteração das posições hierárquicas, ao contrário da geografia rígida do período anterior. O novo sistema pode realizar mais eficaz e equiitativamente do que no passado, devido ao fortalecimento da sociedade local e de suas instituições políticas - fatores endógenos -, a articulação entre sociedade e economia, entre tecnologia e cultura. Isso porque o "global" e o "local" são agora complementares, "criadores conjuntos de sinergia social e econômica, como o foram na alvorada da economia mundial nos séculos XIV a XVI, momento em que as cidades-Estado se constituíram em centros de inovação e de comércio em escala mundial" (idem, 1998, p.14). E, convencidos da capacidade de autodeterminação da sociedade local que souber desenvolver uma boa estratégia de inserção nos fluxos econômicos globais, concluem:

A cidade global não é Nova York, Londres ou Tóquio, ainda que sejam os centros direcionais mais importantes do sistema. A cidade global é uma rede de nós urbanos de distinto nível e com distintas funçôes que se estende por todo o planeta e que funciona como centro nervoso da nova economia, em um sistema interativo de geometria variável ao qual devem 
constantemente adaptar-se de forma flexível empresas e cidades. O sistema urbano global é uma rede, não uma pirâmide. E a relação mutante concernente a esta rede determina, em boa medida, a sorte de cidades e cidadãos. (Idem, 1998, p.43)

Um contraponto à tese da autodeterminação do local na sua articulação com o global pode ser encontrado na obra de Pierre Veltz. Ele compartilha com Borja \& Castells a análise de que o espaço econômico dos anos 90 desenha redes técnicas e financeiras policêntricas que ignoram cada vez mais as fronteiras nacionais, colocando em xeque a própria idéia de "economia nacional", e em que, de certa maneira, "o Terceiro Mundo não existe mais". ${ }^{3}$ Mas sua démarche aponta, num movimento oposto ao daqueles autores, para a cristalização das posições hierárquicas históricas conquistadas pelo "clube dos países ricos".

Analisando dados sobre os investimentos estrangeiros diretos na década de 1990, Veltz observa como eles têm se direcionado preferencialmente para as zonas mais desenvolvidas ou para a Ásia, em detrimento da participação dos demais países, que sofreu uma redução constante e brutal desde o início da década de 1980, mantendo-se, em sua grande maioria, praticamente excluídos do IED. Mas o aspecto mais revelador desta análise é que a maior parte destes investimentos esteve ligada a fusōes e aquisiçõos, e se concentram nos setores de serviços - cerca de 50\% do IED francês e 70\%, do japonês - e não no setor industrial. Ou seja, a repartição desigual dos recursos está relacionada à nova modalidade da divisão internacional do trabalho.

Se as unidades de produção se expandem sobre vastos territórios, em busca de mãode-obra barata, os centros de $\mathrm{P} \& \mathrm{D}$ restam altamente localizados. O progresso técnico e a inovação tecnológica, fontes da competitividade atual, resultam de núcleos de competências autocumulativos e têm sua criação e difusão confinada ao pequeno círculo dos países desenvolvidos, "imbricados em processos históricos e geográficos específicos de gênese e de acumulação" (Veltz, 1996, p.98).

Veltz argumenta de maneira convincente que, se de um lado os imperativos de flexibilidade conduzem o conjunto das firmas internacionais a preferir relaçôes fluidas e reversíveis com os territórios de implantação das unidades produtivas descentralizadas, por outro, no plano do poder e da cultura, os "pertencimentos" nacionais permanecem muito fortes. A imagem da firma cosmopolita e sem pátria é pouco realista, da mesma forma que "conceber a globalização como a extensão universal de um capitalismo homogêneo é um absurdo. Os tecidos socioinstitucionais que existem nos grandes países do 'centro' são poderosos demais para se diluírem em uma tal abstração" (idem, 1996, p.137).

Sim, as grandes firmas do mundo atual continuam sendo americanas, inglesas, japonesas, no máximo binacionais (como a Shell), e isso por várias razões. Em primeiro lugar, porque os principais acionistas são sempre nacionais, possuindo lógicas e interesses distintos próprios de cada país. Em segundo, porque a maioria dos dirigentes destas empresas possuem a mesma origem nacional que a empresa, o que é um critério de escolha comumente utilizado, como mostra uma enquete sobre a gestão das multinacionais francesas. Em terceiro, porque, mesmo nas empresas mais internacionalizadas, a regra é a de que o território de origem continue a captar as atividades mais estratégicas. As despesas americanas com $P \& D$ no estrangeiro representam menos de $10 \%$ do total gasto nesta atividade, e a mesma baixa percentagem de investimento exterior em $\mathrm{P} \& \mathrm{D}$ se verifica no caso da França e no do Japão.

Veltz lembra ainda que a estrutura socioinstitucional nacional desempenha um papel decisivo na retenção destes gastos no território de origem, seja pelas necessárias relações que as empresas mantêm com os bancos ou com o Estado, ou seja mesmo por con-
3 Na medida em que considera que as disparidades econômicas agora se dão em função da integração ou não a estas redes, podendo ser encontradas tanto entre os chamados "países em desenvolvimento", quanto nos países mais ricos, entre zonas integradas à economia mundial e suas "periferias internas" abandonadas (Veltz, 1996, p.85-8). 
ta de estruturas familiares, como no caso das empresas italianas e nipônicas. Às funçôes tradicionais normativas do Estado, sobretudo na regulação da concorrência entre firmas e da moeda, juntam-se aquelas que visam fortalecer as grandes firmas e, ao mesmo tempo, protegê-las das turbulências do mercado internacional, oferecendo-lhes vantagens estruturais, como exemplificam a política de grandes projetos francesa ou o orçamento de defesa americano.

Desta perspectiva, as chances das cidades do Terceiro Mundo integrarem-se aos fluxos econômicos globais por intermédio da atração dos setores "estrategicamente dominantes", de uma outra forma que não seja o tradicional fornecimento de mão-de-obra mal remunerada e precária para a execução de tarefas repetitivas - que, de resto, mais se assemelham à produção industrial do que ao "terciário avançado" - parecem sensivelmente reduzidas. E aqui tocamos no terceiro e último aspecto constituidor do paradigma das global cities que gostaríamos de abordar antes de passarmos à análise das estratégias de desenvolvimento local, que the darão uma verdadeira instrumentalidade. Trata-se das interpretações sobre o crescimento do setor de serviços dissociado da produção industrial, que segue sendo a base material da riqueza das naçôes, dando origem à hipótese da especialização das cidades na "economia de serviços".

\section{As Cidades Como Lugares de Produção Pós-industrial}

4 Dentre os dados que os autores utilizam para tal afirmativa estão os de que os empregos no setor de serviços representavam, em 1987, $71 \%$ dos empregos nos EUA, contrastando com a queda brutal dos empregos industriais (Castells, 1995, p.193); de que nos anos 80 o IED concentrou-se nos setores de alta tecnologia e nos serviços, e na primeira metade do decênio 50\% dele era destinado aos serviços, dos quais $2 / 3$ para atividades ligadas a finanças e ao comércio (Sassen, 1996, p.77-8); e de que os fluxos financeiros equivaleram, no último decênio, a quarenta vezes o volume de recursos movimentado pelas trocas comerciais (Veltz, 1996, p.91).

5 Castells assinala que as "indústrias intensivas em informação" - bancos, transportes aéreos, escritórios centrais de todos os setores, agências comerciais, seguros, financeiras, educação privada, advocacia, engenharia etc. - correspondiam a 13,9\% dos empregos nos EUA, em 1985, e, desta percentagem, 39\% estavam concentrados nas 24 áreas metropolitanas (Castells, 1995, p.218).
Existe um consenso de que a grande maioria das atividades econômicas de todos os países não são globais, permanecendo regionais e nacionais. Todavia, numerosos estudos apontam para a tendência irreversível à internacionalização das grandes empresas, face o processo de reestruturação produtiva com a desintegração da rígida organização industrial taylorista, verticalizada e concentrada, em processos flexíveis em unidades multilocalizadas articuladas por redes telemáticas, processo este facilitado pelas novas tecnologias da informação. Uma das principais conseqüências desta reestruturação produtiva seria o florescimento de uma multiplicidade de empresas de serviços à produção, haja visto que a flexibilidade do sistema, as novas formas de concorrência e a complexidade da gestão de unidades produtivas multilocalizadas assim o requerem.

De fato, todas as estatísticas realizadas nas economias dos países centrais evidenciam o maior dinamismo do setor de serviços à produção em relação aos demais, pois é o que apresenta maiores taxas de crescimento no emprego e na participação do PIB destes países, bem como na participação no total do investimento estrangeiro direto realizado. ${ }^{4} \mathrm{Co}$ mo a matéria-prima processada neste setor é basicamente a informação, elemento agora central da produtividade, gestão e competitividade empresarial na economia globalizada, o modelo espacial dos serviços à produção apresenta uma forte concentração nos grandes centros urbanos, pela conjugação de uma série de fatores (expostos na primeira seção deste trabalho), infra-estruturas apropriadas, mercado de trabalho qualificado etc. ${ }^{5}$

Algumas cidades dos países líderes deste processo de internacionalização teriam assistido a uma rápida mudança no perfil do emprego, decorrente do dinamismo do setor de serviços nelas presente, sendo Nova York o exemplo mais paradigmático desta reestruturação econômica. De acordo com Castells (1995, p.297), entre 1977 e 1987, 70\% dos novos empregos criados nesta cidade foram no setor de "serviços avançados" - em torno de 342.000 -, enquanto 539.000 empregos industriais foram perdidos.

Mas até que ponto esta mudança no perfil do emprego não representa apenas um deslocamento de atividades técnicas e de gestão antes desenvolvidas no interior das indús- 
trias, tratando-se apenas de uma questão de nomenclatura, e, desta forma, não representando um maior dinamismo da economia nova-iorquina que pudesse transformá-la em modelo de desenvolvimento econômico local a ser perseguido por outras localidades no mundo? Até que ponto esta expansão do emprego no setor de serviços não expressa uma particularidade da cidade de Nova York, a liderança de sua bolsa de valores no sistema financeiro internacional e o fato de os EUA serem os maiores investidores e captadores do IED, condiçōes absolutamente inexistentes em outras partes do mundo?

Segundo Sassen (1996, p.209), a tendência a um mercado de trabalho urbano dominado pelos serviços é uma realidade que se apresenta tanto em Nova York, como em Londres e Tóquio, embora a proporção dos serviços ditos "avançados" seja relativamente baixa em relação ao conjunto. Somados todos os serviços à produção - nem todos caracterizados pelo processamento de informação -, em 1987, eles correspondiam a 37,7\% dos empregos de Nova York e a 32,8\% dos de Londres. Considerando apenas bancos, finanças e seguros, os serviços mais internacionalizados, eles representavam apenas $4,2 \%$ do total de empregos de Tóquio, 10,2\% dos de Londres e 13,9\% em Nova York.

Outro dado interessante é que os centros financeiros destas cidades vêm gradativamente reduzindo sua participação no total de empregos urbanos. Manhattan, que detinha 40,6\% dos empregos da região metropolitana de Nova York em 1956, decresceu sua participação no emprego desta região para 29,1\% em 1975, caindo mais ainda em 1985, quando contribuía com apenas $27,2 \%$. Sassen (1996, p.213) interpreta estes dados como indicadores de uma redistribuição do emprego, com a descentralização de algumas atividades, especialização e concentração do emprego em finanças e negócios em Manhattan.

Duas observações nos parecem relevantes com base nestes dados. Primeiro, que, embora os serviços avançados sejam responsáveis por maiores taxas de crescimento do emprego, no cômputo geral do emprego urbano eles contribuem com uma parcela reduzida. A maior parte da mão-de-obra local é empregada nas atividades rotineiras ligadas aos serviços à produção, nos serviços pessoais e sociais, nas atividades tradicionais da indústria e do comércio, administração pública ou na economia informal, que apresenta igualmente taxas de crescimento extraordinárias em cidades como Los Angeles e Nova York, representando a outra face da cidade global. ${ }^{6}$

Em segundo lugar, estas taxas elevadas de crescimento do emprego nos serviços ligados ao processamento da informação está sendo verificada naquelas cidades que já eram centros financeiros e de serviços importantes nos seus respectivos países, há pelo menos algumas décadas. Em Nova York, o distrito financeiro de Manhattan já detinha 40\% do emprego urbano, em 1956! Paris, como mostra Veltz (1996, cap.I), beneficiando-se da descentralização da indústria francesa em direção a outras regiōes do país, iniciada na década de 1950, passou desde então a concentrar e a se especializar nas atividades de gestão, finanças e demais serviços. A construção do distrito financeiro parisiense - La Défense -, com efeito, data de 1958, ou seja, no auge dos Trinta Gloriosos anos do fordismo!

Ou seja, em que pese o crescimento da demanda por serviços técnicos e de gestão, resultante da dispersão geográfica das unidades produtivas e da expansão dos setores financeiro e industrial dos países líderes do investimento estrangeiro direto mundial, ter proporcionado um aumento do emprego urbano ligado à prestação de serviços naquelas cidades que se constituem como seus centros de comando e controle, esta já era uma tendência histórica. O que surge como novidade então parece ser a queda dos empregos industriais urbanos, o que deve ser igualmente relativizado, devido à subcontratação de tarefas antes desempenhadas no interior das fábricas.
6 Segundo Castells, uma proporcão crescente de migrantes e de minorias étnicas não encontra emprego adequado na cidade de Nova York; $49,5 \%$ da força de trabalho nova-iorquina, em 1987, era composta por minorias étnicas, que são as mesmas que apresentavam as maiores taxas de evasão escolar e estavam expostas à qualidade decrescente do sistema escolar público; os migrantes, sobretudo os clandestinos, são o exército que alimenta o crescimento da economia informal, que vai desde pequenas indústrias domésticas não-regulamentadas a táxis piratas e trabalhadores externos de fábrica, que somavam cerca de $20 \%$ da mão-de-obra da indústria têxtil. A cidade global é a cidade dual (Castells, 1995, cap.V). 
7 Borja \& Castells argumentam que o padrão de localização verificado nas indústrias de tecnologias de informação é extensivo a todo o conjunto da estrutura industrial, na medida em que a microeletrônica se difunde na maquinaria e nos processos de produção de todos os ramos industriais (Borja \& Castells, 1998, p.43).

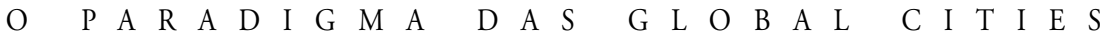

Estas divisões estatísticas tradicionais entre os setores primário, secundário e terciário são hoje completamente anacrônicas. A estrutura da organização produtiva é atualmente constituída por arquiteturas logísticas que integram operações de produção e distribuição de bens e serviços complexos, como aquelas que associam mercadoria, crédito ao consumidor e assistência técnica. A concepção de uma empresa como um lugar que produz um bem material ou um serviço específico se tornou ultrapassada (idem, 1996, p.152).

Da mesma maneira que não é possível pensar no desenvolvimento dos serviços avançados sem a obrigatória articulação destes com a produção material de bens, imaginar que os primeiros possam florescer nas cidades sem uma profunda interação com o tecido econômico produtivo regional e nacional seria um despropósito que não encontra correspondência na construção histórica concreta, nem das sociedades dos países capitalistas centrais, nem daquelas onde o capitalismo se desenvolveu mais tardiamente, como as dos continentes asiático e australiano. Nestes últimos, como assinala Sassen, a concentração de serviços nas grandes cidades foi igualmente possível graças ao desenvolvimento da economia regional e nacional:

O caso de Sidney ilustra a interação de uma economia em larga escala, a de um continente, e as pressões à concentração espacial. ... Os eventos dos anos 80 - aumento da internacionalização da economia australiana, forte crescimento do investimento estrangeiro, nítido deslocamento em direção às atividades financeira e imobiliária e aos serviços às empresas - contribuíram para uma forte concentração das atividades e dos atores econômicos em Sidney. (1995, p.44)

Por outro lado, a idéia de que não existem alternativas para as cidades fora do desenvolvimento das atividades de serviços articulados às redes dos fluxos econômicos globais é fortemente influenciada por pesquisas empíricas sobre o modelo de localização espacial da indústria de alta tecnologia e de informática, e das atividades financeiras, ${ }^{7}$ mas este modelo de forma nenhuma corresponde ao conjunto dos distintos "mundos da produção" existentes, pois nem todos têm a inovação tecnológica como incremento essencial de produtividade (Salais \& Storper,1993; Veltz,1996).

Isto porque as grandes empresas produtivas inscrevem-se diferentemente nos processos de internacionalização, face suas funções estratégicas do ponto de vista da competição, o que repercute em relações espaciais distintas. Nos setores onde as funções estratégicas são o marketing, a inovação comercial, a pesquisa ligada ao consumo, ou a produção propriamente dita - como nos setores alimentar, farmacêutico e automobilístico -, a proximidade aos mercados é ainda fundamental para superar políticas protecionistas, dominar as regras nacionais, captar e influenciar os gostos, tradições e hábitos de consumo ou simplesmente reduzir custos. Até que ponto podemos falar em globalização nestes setores? (Veltz, 1996, p.127).

Não obstante as distintas articulações, de base regional e nacional, que estes setores estabelecem com as cidades, as inúmeras implantações industriais que se multiplicam em áreas urbanas e metropolitanas - sobretudo aquelas dos setores de moda, audiovisual, da microinformática e gráfico - atestam a pluralidade de formas de desenvolvimento econômico local que não podem se reduzir à vocação tal como proposta pelo paradigma das global cities. 


\section{AS ESTRATÉGIAS DE DESENVOLVIMENTO LOCAL}

As estratégias de desenvolvimento local que são oriundas do paradigma das global cities têm como pressuposto que fatores endógenos poderão favorecê-lo, desde que se saibam interpretar as dinâmicas econômicas dominantes e as possibilidades de nichos de mercado que possam ser exploradas para a inserção competitiva da cidade nas redes dos fluxos dos capitais internacionais. Entre os fatores endógenos responsáveis pela atratividade destes fluxos de capitais, encontram-se transformaçôes, tanto políticas e institucionais quanto físicas, que sejam capazes de fornecer as condiçôes para melhor "vender a cidade" no contexto de uma competição interurbana impulsionada pela globalização.

Numa postura mais politicamente pragmática que teórica, os autores que elaboram esta concepção de estratégia sustentam-na empiricamente com a enumeração de exemplos de experiências bem-sucedidas de localidades que conseguiram se inscrever na rede de fluxos econômicos globais mediante uma autodeterminação dos atores políticos locais. Como revelam Borja \& Castells :

As cidades asiáticas demonstraram que no mundo da economia global a velocidade da informação sobre os mercados internacionais e a adaptação aos mesmos, a flexibilidade das estruturas produtivas e comerciais e a capacidade de inserir-se nas redes determinam o êxito ou o fracasso, muito mais que as posiçōes adquiridas no passado, o capital acumulado, as riquezas naturais ou a situação geográfica. O segredo reside na velocidade de inovar do tecido de pequenas e médias empresas articuladas com grandes empresas em rede, no que diz respeito ao exterior, e com o poder político, em relação ao interior. (1998, p.141)

Adaptar-se aos mercados internacionais é a única alternativa possível para o desenvolvimento econômico das cidades na visão destes autores, na medida em que têm a convicção de que "na sociedade da informação, o global condiciona o local e os fluxos eletrônicos estruturam a economia a partir de relaçôes entre unidades espacialmente distantes" (idem,1998, p.12). Para tanto, os principais atores políticos e econômicos locais deverão elaborar uma estratégia de antecipação aos novos requerimentos da economia global e da competitividade internacional, promovendo transformaçōes na infra-estrutura urbana, na qualidade de vida e na formação de recursos urbanos, aliada a uma estratégia de marketing urbano que promova a cidade no exterior.

Esta visão da subordinação do local ao global é compartilhada por Ascher (1995, cap.VI), para quem as grandes metrópoles são sistemas complexos determinados em parte por fenômenos externos que os responsáveis públicos não podem dominar. Este novo contexto impõe uma mudança radical na concepção da política urbana, substituindo-se a idéia da intervenção - essência do urbanismo moderno - pelas de atração, acompanhamento e negociação, que se traduzem num novo modelo de gestão urbana ao qual o autor denomina de "empresariamento urbano estratégico".

A recorrência a expressões características dos métodos de gestão de empresas não é casual. A absorção destes métodos na elaboração de planos estratégicos de cidades (instrumentos de legitimação privilegiados nos processos de reestruturação econômica e urbana de algumas cidades como Barcelona, Amsterdã, Lyon, Lisboa, Rio de Janeiro, Bogotá, entre outras) supóe que as grandes cidades têm hoje muitos traços em comum com as grandes empresas: dependem dos mesmos fatores econômicos, enfrentam a concorrência internacional e gerenciam serviços, atividades produtivas e recursos humanos (idem,1995, p.213). 
A noção de cidade-empresa é ainda justificada pela idéia de que, no marco da economia global, o futuro das cidades dependerá da competitividade das empresas nelas instaladas, competitividade esta que, por sua vez, tem nos recursos territoriais específicos as suas condiçōes fundamentais, tais como: infra-estruturas de suporte às atividades econômicas; conexão a redes internacionais; formação profissional; qualidade dos serviços públicos etc. (Forn, 1993, p.3).

A lógica simbiótica da cidade-empresa é ambivalente à da cidade-mercadoria, que deve promover sua imagem no exterior com vistas a exercer a atração de investidores, e ao mesmo tempo facilitar suas "exportaçôes" de bens, serviços e profissionais. Ambas atribuem aos governos locais uma espécie de papel de capitalista coletivo, na medida em que "a mercadotecnia da cidade, vender a cidade, converteu-se, portanto, em uma das funçōes básicas dos governos locais e em um dos principais campos de negociação público-privada" (Borja \& Forn, 1996, p.33).

Vejamos agora com mais detalhe o que consistem estas estratégias de venda.

\section{A Passagem do Modelo Espacial Industrial para o do Terciário AvanÇado}

Os modelos do urbanismo, desde o século XIX, sempre foram influenciados pelas necessidades econômicas e pelas exigências sociopolíticas do período a que correspondiam, embora estes modelos não tenham se realizado plenamente nas cidades, pela pesada inércia do ambiente já construído. No período fordista, iniciado no pós-guerra, o planejamento e a reconstrução das cidades européias expressava a divisão social do trabalho - por meio do zoneamento residencial e dos grandes conjuntos habitacionais que acolhiam os trabalhadores e as camadas médias - , a maximização das economias de escala - com a organização "científica" do território e da distribuição da infra-estrutura urbana -, bem como os avanços tecnológicos nos transportes e nas comunicações.

No período atual, com a dispersão geográfica da produção e a concentração das funções de comando, inovação e gestão nas cidades, os novos imperativos do urbanismo passaram a ser:

a) a construção de redes de comunicação em fibra ótica - que permitem uma maior qualidade e segurança na transmissão de dados - fornecidas em instalações apropriadas para escritórios e sedes de empresa, que são os chamados "edifícios inteligentes";

b) a criação de distritos financeiros nas estações terrestres de telecomunicaçôes (teleportos), que propiciem economias de aglomeração e externalidades positivas para este setor;

c) a modernização e/ou construção das infra-estruturas de transporte de alta velocidade, como aeroportos e TGVs, para assegurar a mobilidade e a acessibilidade física;

8 Ascher qualifica estas novas camadas sociais como aquelas "estratégicas", "qualificadas e não-precarizadas", para as quais a abundante oferta residencial e as intervenções urbanas destinadas aos bairros onde se concentram deve considerar um certo conteúdo simbólico, elas devem "marcar a imagem" do novo status social adquirido (Ascher, 1995, p.233). d) a provisão residencial - permanente e transitória - destinada às novas camadas profissionais médias e aos quadros executivos das empresas, ${ }^{8}$ como hotéis e residências de luxo, condomínios fechados ou novos loteamentos que ofereçam qualidade de vida, em áreas dotadas de equipamentos comerciais, culturais, esportivos e de lazer.

O urbanismo do período pós-fordista também expressa a divisão social do trabalho - não mais predominantemente industrial, mas do terciário avançado -, na segregação residencial da nova classe emergente, na "gentrificação" das áreas centrais renovadas, e no abandono das classes populares, quando as preocupações com a provisão habitacional destinada a elas deixa de constar dos documentos do urbanismo, assim como das prioridades de investimentos públicos, agora voltadas para intervençôes pontuais e fragmentadas nas zonas "integradas" do tecido urbano. 
Um aspecto interessante deste novo modelo é que ele pretende ser indutor de um processo de desenvolvimento econômico, ao invés de ser determinado por ele, como no modelo anterior. A estratégia da antecipação, uma arma essencial na guerra da competição interurbana, baseia-se na observação e tentativa de reprodução de experiências bemsucedidas em outras partes do mundo, contribuindo para minimizar os riscos de uma má aplicação dos recursos públicos. A difusão de experiências torna-se, assim, a principal tarefa e um mercado de trabalho espetacular que se abre aos consultores internacionais, os novos vendedores do futuro e da esperança.

... tão logo uma região do mundo se articula à economia global, dinamizando sua economia e sociedade locais, o requisito indispensável é a constituição de um núcleo urbano de gestão de serviços avançados organizados, invariavelmente, em torno de um aeroporto internacional; um sistema de telecomunicações por satélite; hotéis de luxo, com segurança adequada; serviços de secretariado em inglês; empresas financeiras e de consultoria com conhecimento da região; oficinas de governos regionais e locais capazes de proporcionar informação e infraestrutura de apoio às inversões internacionais; um mercado de trabalho local com pessoal qualificado em serviços avançados e infra-estrutura tecnológica. (Borja \& Castells, 1998, p.37)

O que mais surpreende na difusão destas experiências é a atribuição ao voluntarismo e à ousadia dos responsáveis políticos, o sucesso pela articulação à economia global. Exemplos como o de Birmingham - "que mediante um plano estratégico ... renovou seu centro urbano e se converteu na cidade inglesa mais dinâmica” - ou os de Amsterdã e Lyon que por meio de seus planos estratégicos "se adiantaram à crise e promoveram mudanças na infra-estrutura e na imagem para adequar-se aos novos requerimentos da economia global e da competitividade internacional" - são reproduzidos à exaustão, na tentativa de convencer os governos locais interessados que a saída da crise econômica na qual se encontram suas cidades depende apenas da tomada de consciência do agravamento da crise com a globalização; da concertação dos atores urbanos e geração de uma liderança política local para a elaboração de um bom plano estratégico; e da vontade conjunta para implementar as transformaçōes físicas, econômicas e sociais que se façam necessárias (idem, 1998, p.146).

\section{O MARKETING URBANO}

Seguindo a mesma lógica do marketing empresarial, a estratégia da promoção das cidades no exterior apóia-se na existência de um bom produto que possa ser ofertado aos investidores estrangeiros e que atenda suas exigências sofisticadas. Este produto é um produto complexo que se constitui não só de infra-estruturas materiais e serviços urbanos, mas também de competências e qualidades sociais específicas. Se, por um lado, as infraestruturas materiais tendem a se banalizar pela concorrência, as competências dos trabalhadores e os valores culturais e sociais são inerentes ao lugar, podendo, por esta razão, se traduzir em vantagens comparativas para as empresas que neste lugar se estabelecerem.

A construção de uma "marca" para a cidade consiste então no diagnóstico das potencialidades econômicas e sociais, face uma avaliação da demanda das empresas ou setores-alvo, seguido da definição dos aspectos positivos e negativos que deverão ser ressaltados ou modificados na divulgação da imagem da cidade. Invariavelmente, a imagem que se tenta construir é a de uma cidade empreendedora, socialmente integrada, que oferece qualidade de vida e um "clima" favorável aos negócios. 
Além das formas tradicionais de city marketing - campanhas publicitárias, eventos culturais e esportivos etc. - a promoção da cidade deve incluir a realização de feiras e exposiçôes, a ordenação e promoção de áreas comerciais, a recuperação de centros históricos e áreas portuárias, melhorias das infra-estruturas de acessibilidade e comunicaçôes, bem como reserva de áreas para implantação de novos negócios (Borja \& Forn, 1996, p.34). Entretanto, a realização de grandes eventos internacionais - como os Jogos Olímpicos, Fórum Global, congressos, etc. - podem também converter-se num poderoso mecanismo de captação de recursos e investimentos que permitam impulsionar um processo de transformação urbana e de dinamização econômica, como atestam as experiências de Barcelona e Lisboa (Borja \& Castells, 1998, p.145).

Com efeito, segundo Harvey, a mobilização do espetáculo - desde eventos "midiáticos" e esportivos, construção de shoppings, até a renovação de centros históricos - é um dos traços mais característicos do urbanismo pós-moderno americano utilizado, ao mesmo tempo, como instrumento e como símbolo de unificação política, que comporta um sentido do efêmero, da publicidade, do prazer compartilhado.

O prefeito Schaefer e a aliança de classes urbanas que o sustenta em Baltimore têm utilizado conscientemente o espetáculo da praça do Porto desta maneira, enquanto símbolo da suposta unidade de uma cidade dividida em classes e racialmente segregada. As atividades esportivas profissionais e os eventos como os Jogos Olímpicos de Los Angeles têm preenchido uma função similar numa sociedade urbana muito mais segregada. (Harvey, 1995, p.132)

A construção deste "capital simbólico" sublinhado por Harvey, todavia, não se destina apenas à atração dos investidores, mas também a fomentar a adesão do conjunto dos segmentos sociais presentes na cidade às transformações econômicas e urbanas necessárias, uma vez que elas significarão prioridades de investimentos em detrimento de outros, talvez socialmente mais urgentes ou relevantes. A estimulação do "patriotismo cívico" dos moradores da cidade, da noção de "pertencimento", vontade de participação e confiança no futuro da cidade, é, neste sentido, um papel importante atribuído aos governos locais, cuja política de promoção interna

... deve apoiar-se nas obras e serviços visíveis, tanto os que têm um caráter monumental e simbólico, como os dirigidos a melhorar a qualidade dos espaços públicos e o bem-estar das pessoas. (Borja \& Castells, 1998, p.154)

Entre estas obras visíveis, destaca-se a renovação urbana de centros históricos e áreas portuárias degradadas, implementadas em numerosas localidades como Londres, Baltimore, Barcelona, Buenos Aires, entre outras. Estas operações imobiliárias constituem uma excepcional oportunidade de captura de investimentos externos e internos, já que a significativa valorização que lhe é decorrente exerce forte atração sobre grandes empresas incorporadoras e capitais especulativos. Concomitantemente, elas viabilizam a dotação de infra-estruturas culturais, de lazer e de negócios - anfiteatros, marinas, centros de convençôes, novas áreas de escritórios etc. -, igualmente interessantes do ponto de vista do marketing urbano, além de criar um imaginário de progresso e de recuperação econômica, seja ela real ou fictícia, que contribui para o consentimento dos moradores. 


\section{CONCLUSÃO}

As novas estratégias de desenvolvimento local que vêm sendo difundidas nos países do Terceiro Mundo têm como pressuposto que a nova geografia do espaço financeiro e industrial mundial redefiniu o papel das cidades como lugares de comando e de gestáo sobre os fluxos de capitais, mercadorias e informaçôes. Embora tenham já surgido pela necessidade do controle militar, político-administrativo e econômico sobre os territórios, as cidades perderam seu poder e autonomia com o advento dos Estados nacionais, e estariam agora recuperando parte deles ao protagonizar as condiçóes gerais da produtividade do sistema global.

Dentre estas condiçóes gerais encontram-se infra-estruturas materiais e recursos sociais específicos ao tratamento da informação, elemento essencial para o gerenciamento do sistema produtivo organizado em redes de unidades multilocalizadas. Este modelo de organização produtiva que combina descentralização, decomposição de processos, e recentralização de funções de controle, observado por Castells, sobretudo, na indústria de alta tecnologia e de informática americanas, seria extensivo ao conjunto da estrutura industrial, na medida em que a microeletrônica se desenvolve na maquinaria e nos processos de produção de todos os ramos industriais.

Mesmo que a automação e a decomposição do processo de produção seja, de fato, uma tendência verificada em todos os setores industriais, talvez ela não engendre os mesmos processos espaciais para o conjunto destes setores, pois, como sugere Veltz, e também Salais \& Storper, outros fatores, como tipo de concorrência a que estejam submetidos, função estratégica, tipo de produto e até mesmo a participação do Estado na economia como no caso francês -, podem intervir na lógica da organização e, conseqüentemente, na localização empresarial de cada um deles diferentemente.

Este é o primeiro elemento paradigmático do pressuposto teórico que sustenta as novas estratégias de desenvolvimento local. Evidentemente, nos faltam elementos de análise para avaliar a validade de uma tal hipótese, nem tivemos aqui esta pretensão. Todavia, os exemplos, que se multiplicam, de implantações industriais, sejam grandes empresas verticalizadas ou distritos de pequenas e médias empresas, mas que reúnem numa mesma localização todas as etapas do processo de produção, tanto no Brasil - como no caso da Renault, em Curitiba, e da Volkswagem, em Rezende -, quanto em outras partes do mundo - como no caso dos distritos industriais da Terceira Itália, de Los Angeles, das regiôes de Toulouse e Grenoble, entre outros -, nos permite questionar o caráter premonitório e incontestável desta argumentação.

O segundo elemento paradigmático, decorrente da aceitação do primeiro, é a vocação específica das cidades para o terciário avançado, isto é, para as atividades intensivas em processamento da informação que dão capacidade de controle globalizado sobre a rede de unidades produtivas descentralizadas e sobre o fluxo de capitais. Ele sugere que, com a redução dos custos dos transportes e os avanços tecnológicos nas comunicações, as economias de aglomeração que conduziram as indústrias aos centros urbanos no passado teriam sido eliminadas para este setor, continuando válidas apenas para o setor de serviços. Os exemplos utilizados anteriormente também se aplicam no questionamento deste segundo argumento.

Que as cidades apresentam forte potencialidade para o desenvolvimento de atividades ligadas aos serviços, isto é inegável. Mas uma cidade pode ser muitas coisas. Suas funções políticas, administrativas, comerciais, financeiras gestionárias ou mesmo industriais, 
dependeram sempre de sua inscrição no território, isto é, no tecido econômico e social compreendido num dado limite político-administrativo, seja ele a região, o continente ou a nação. É a noção de território que está sendo agora colocada em xeque. As cidades passam a ser determinadas pela posiçãa que ocupam na rede de fluxos econômicos globais, desterritorializados, fluxos virtuais. As cidades são os nós de conexão desta rede e, por esta razão mantêm relações privilegiadas com outras localidades a elas conectadas, e não mais com seu hinterland ou com o espaço regional ou nacional.

Este é o terceiro elemento paradigmático. A articulação do local com o global. A esfera nacional deixa de ser um nível de análise pertinente, porque os fluxos econômicos com a integração dos mercados ignoram as fronteiras político-administrativas do Estadonação. As últimas funções reguladoras que restariam aos Estados nacionais estariam sendo aniquiladas com a constituiçãao dos blocos econômicos, a unificação de moedas e o poder militar supranacional da ONU, entre outras medidas de sua superação. E, na ausência das capacidades reguladoras do Estado-nação, as localidades não teriam outra alternativa a não ser subordinar-se às exigências de mobilidade e competitividade dos capitais globais.

O debate sobre a importância do Estado no quadro de globalização econômica é central para a compreensão a respeito dos impactos que desta incidirão sobre as cidades e a esfera local de decisão. Contudo, consideramos que as mudanças no âmbito institucional e político que garantirão a estabilidade e a continuidade do novo regime de acumulação ainda estão em curso, sendo desta maneira ainda cedo para analisar a consecução das tendências antecipadas pela hipótese da articulação do local e do global sem a intermediação da escala nacional de regulação econômica.

O que nos parece seu aspecto mais problemático, no entanto, é a aceitação da subordinação aos interesses econômicos do capital global como uma fatalidade, fatalidade esta que conduz a comportamentos oportunistas, egoístas e competitivos, e a localismos exacerbados por parte dos governos e representantes políticos locais. A própria idéia de um desenvolvimento que se encerra nos limites administrativos de uma cidade ignorando sua periferia marginalizada e excluída, é, em si, uma idéia liberal e conservadora.

A competição interurbana é estimulada pela sensação de crise mas também pela ação dos consultores internacionais que atribuem o suposto "sucesso" de determinadas localidades ao seu voluntarismo e ousadia e, claro, ao cumprimento da agenda "estratégica" de transformaçōes exigidas para a inserção econômica da cidade nos fluxos globais. Nenhuma palavra sobre conjunturas macroeconômicas que levaram o capital a investir em tal ou qual localidade. Tudo depende da mobilização de vontades coletivas e outros fatores endógenos.

Todas as estratégias de atração de empresas e investimentos, orientadas a responder antecipadamente aos requisitos de produtividade e competitividade das firmas, que expusémos na terceira parte do presente trabalho, são socialmente segregadoras. Elas se traduzem em inversões volumosas de recursos públicos em grandes obras de infra-estrutura, melhorias dos espaços públicos, provisão de equipamentos urbanos e operaçóes imobiliárias destinadas apenas a certos tipos de usuários, aos executivos das grandes empresas e as novas camadas profissionais "estratégicas" do terciário avançado.

O alto custo social desta priorização de gastos orçamentários por administrações locais que viram suas atribuições e responsabilidades acrescidas com o desengajamento dos Estados nacionais e das políticas sociais compensatórias e com a crise econômica, sobretudo nos países do Terceiro Mundo, onde existem déficits sociais há décadas acumulados, é compensado pelo dinamismo econômico resultante da inserção aos fluxos econômicos globais? 
Em primeiro lugar, é preciso considerar se os critérios de escolha da localização, ou da relocalização das empresas que atuam no setor financeiro e de serviços à produção são sensíveis às vantagens comparativas oferecidas pelo marketing das cidades competidoras. A extrema concentração das funções de comando financeiro, controle, gestão e concepção de processos e produtos nas grandes cidades dos países centrais, sublinhada por todos os autores, indica o alcance limitado destas estratégias. Fatores como segurança, relações privilegiadas com instituições públicas ou privadas locais, nacionalismos e maior qualificação do mercado de trabalho, contribuem pesadamente para esta inércia das firmas em seus países de origem. Por outro lado, a abertura de filiais no exterior só é motivada, nestes setores, pela expansão da demanda das grandes empresas por prestação localizada de serviços de nível internacional ou pela expansão do IED, que dinamiza um determinado mercado financeiro secundário.

Em segundo, mesmo nas "cidades globais" que são os centros financeiros da economia global, como Los Angeles e Nova York, o processo de dualização social é acelerado. O distanciamento crescente entre integrados e excluídos nestas cidades, a explosão da violência e da economia informal, a "precarização" das relações de trabalho, a delinquência juvenil e o aumento do número de dependentes de drogas são alguns aspectos que têm levado diversos autores a considerar que as sociedades centrais vivem hoje um processo de "terceiromundização". Qual futuro poderá este modelo de progresso, segregador e excludente, reservar às nossas cidades e aos nossos povos?

\section{REFERÊNCIAS BIBLIOGRÁFICAS}

ASCHER, F. Métapolis ou l'avenir des villes. Paris: Odile Jacob, 1995.

BENKO, G., LIPIETZ, A. Les régions qui gagnent. Paris: PUF, 1992.

BORJA, J., CASTELLS, M. Local y global. La gestión de las ciudades en la era de la información. Madri: Taurus, 1998.

. "As cidades como atores políticos". Novos Estudos Cebrap, n.45, p.152-66, 1996.

BORJA, J., FORN, M. de. "Políticas da Europa e dos Estados para as cidades". Espaço \& Debates, ano XVI, n.39, p.32-47, 1996.

CASTELLS, M. La ciudad informacional. Tecnologías de la información, reestructuración económica y el proceso urbano-regional. Madrid: Alianza Editorial, 1995.

FORN, M. de. "Estratégias de transformación urbana y economica". Barcelona, 1993. (Mimeo.)

HARVEY, D. Condição pós-moderna. São Paulo: Ediçōes Loyola, 1994.

. "Do gerenciamento ao empresariamento: a transformação da administração urbana no capitalismo tardio". Espaço \& Debates, ano XVI, n.39, p.121-45, 1996.

"L'accumulation flexible par l'urbanisation: réflexions sur 'post-modernisme' dans la grande ville americaine". Futur Antérieur, Paris, n.29, 1995/3, p.121-45.

SALAIS, R., STORPER, M. Les mondes de production. Enquête sur l'identité économique de la France. Paris: Éd. de l'EHESS, 1993.

SASSEN, S. La ville globale. New York, Londres, Tokyo. Paris: Descartes \& Cie, 1996. . "L'État et la ville globale: notes pour penser l'inscription spatiale de la gouvernance". Futur Antérieur, Paris, n.30/31/32, 1995/4, p.27-49.

Cities in a World Economy. Thousand Oaks, CA: Pine Forges Press, 1994.

SCOTT, A. J. "L'économie métropolitaine: organisation industrielle et croissance ur-
Rose Compans é arquiteta, doutoranda no IPPUR/ UFRJ, e trabalha no Instituto Municipal de Urbanismo Pereira Passos (Prefeitura da cidade do Rio de Janeiro). E-mail: compans@unisys.com.br. 
baine”. In: BENKO, G., LIPIETZ, A. Les régions qui gagnent. Paris: PUF, 1992. p.103-20.

SOJA, E. W. Geografias pós-modernas. Rio de Janeiro: Jorge Zahar, 1993.

VELTZ, P. Mondialisation, villes et territoires. L'Économie d'archipel. Paris: PUF, 1996.

A B S T R A C T This article discusses the new development economic strategies for cities in the productive restructuration context. It focuses the role of the great cities like management centers of the capital fluxes which allows an articulation between the local and the global spaces without the mediation of the regional and national spheres. At first it introduces some theoretical contributions about the emergence of an flux economy, which net organization format requires that the cities turn themselves connection points, as a strong influence in Third World urban debate. Afterwards it analyses the paradigmathical arrangement of the "global cities" with the support of general concepts and empirical dates. At last but not least, the paper also argues the supposed natural vocation of the cities nowadays for the advanced Tertiary, as show the several strategies diffused and recommended by international experts.

K E Y W O R D S Local development; urban management; globalization; global cities. 